The ACRL Subcommittee on Goals, Priorities, and Structures, chaired by Le Moyne W. Anderson, director of libraries, Colorado State University, is completing a monumental three-year study which has attempted to develop an organizational structure for ACRL that can respond both to the welfare of the profession and to the issues of library services in the changing environment of academic libraries. The subcommittee's semifinal draft report proposes a radical restructuring of the association, better to meet changing needs. During the coming year, the report will be given careful study. Implementation of any or all of the report's recommendations will be subject to ACRL Board approval.

In an attempt to increase membership in the association, the chairperson of ACRL's Membership Committee, Thomas H. Cahalan, assistant librarian for acquisitions, Northeastern University, has developed a promotional network comprising regional and state representatives throughout the United States and Canada. It is hoped that working through regional groups and chapters will stimulate increased in- terest in ACRL and its programs. Special brochures have been developed for use in state and regional meetings, and their effectiveness will be evaluated to determine the best ways to reach potential members.

The specialized interests of ACRL's committees and sections are so diverse and wide-ranging that space does not permit adequate reporting of all of them. All have served their constituencies well and have continued to make important contributions to their areas of special interest as well as to the association. The success of ACRL's programs and their impact on the profession are directly attributable to the combined energy, talent, and dedication of ACRL officers and committee members.

The association mourned the tragic loss of its immediate past president, Louise Giles. She had been an unusually active and productive participant in ACRL and ALA affairs, and her absence will be keenly felt for many years.

Connie R. Dunlap

President, ACRL

\title{
Yale Center for British Art Opened
}

A new museum and study center-the Yale Center for British Art-was officially opened to the public April 19 in New Haven.

The gift of Paul Mellon (Yale class of 1929), the center will house Mellon's unrivaled collection of British paintings, drawings, prints, and rare books. The center will offer reference material for advanced research in the field of British art; classrooms; and other facilities for a broad program of activities in British studies.
The addition of the Mellon collection to the university's already extensive holdings of English books and autograph letters makes Yale a leading institution for the study of British art and culture outside of England.

The center is the final building designed by the late Louis I. Kahn (1901-74), internationally distinguished architect, who also designed the Yale University Art Gallery (1951-53) and the Kimbell Museum in Fort Worth, Texas
The reference library is located on the second floor, with a photographic archive and storage stacks housed on the mezzanine above.

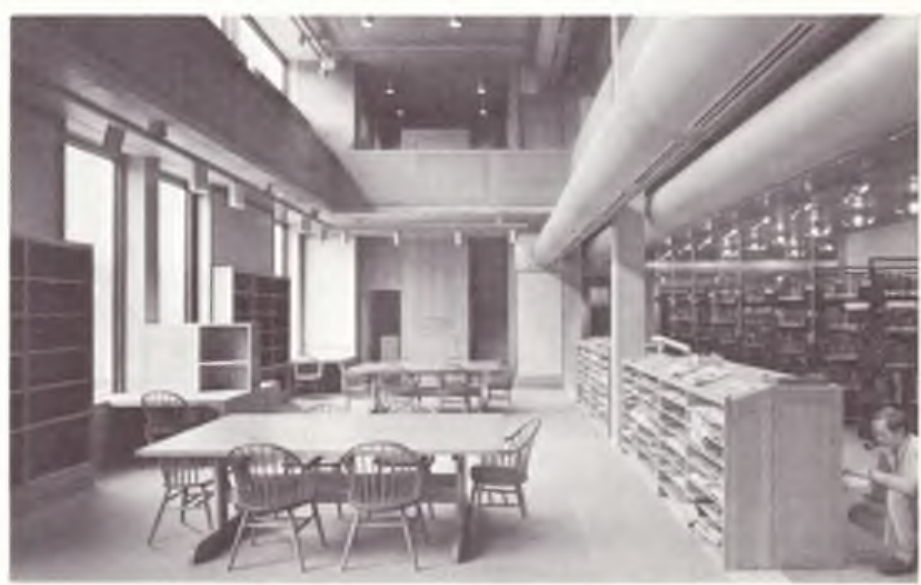


(1969-72). The four-story structure, noted for its innovative system of lighting, brings natural light into the exhibition spaces through the unique combination of filtered skylights, plate glass windows, and two interior courts.

Mellon's gift of the British art center continues his long record of support to Yale since his graduation in 1929. Gifts from Mellon and the Old Dominion Foundation, of which he was chairperson, have made possible the restoration of Connecticut Hall, the construction and endowment of Morse and Ezra Stiles Colleges, the purchase of the Boswell papers and other books for the Yale Library, as well as the underwriting of numerous academic programs.

When this gift was announced in 1966, Mellon emphasized his belief that the university, with its already recognized pre-eminence in British literary and social studies, was the logical choice as the recipient of his British collec- tions. "It seems to me," he said, "that Yale, with its great holdings in British literary and social research material, such as the Walpole and Boswell papers, can make the best use of the resources of my collections for educational and historical purposes. . . . In addition, it was at Yale as an undergraduate that my personal interest in English literature and art began in earnest, and I have always been deeply grateful to the university for this fact.'

Long a leader in eighteenth-century studies, Yale now possesses the visual resources for thorough study of the interrelationships of British art, literature, and history, according to Yale President Kingman Brewster, Jr., who stated that "Mr. Mellon's gift makes a major contribution to the cultural vitality of the city and to Yale University, and in a broader sense, to the cultural resources of the nation."
Dear Editor:

The following opinion may have grown beyond an appropriate length for a "letter to the editor," but it is a point of view which should be given wider consideration. The question which prompts the commentary has significance for more people than simply those to whom the response is immediately directed.

What are the major issues confronting undergraduate librarians today?

The answers will vary, of course, since an issue which looms as significant in one situation may be insignificant in another. Or an issue in one setting may be perceived in another as a mere need to exchange ideas and information. On the other hand, there are factors which distinguish real issues from matters more efficiently resolved at a personal level of information exchange and decision making. For example, issues are always preceded by inquiries and the identification of problems or matters of concern which are not easily resolved. These become issues as they are addressed as points of debate or controversy, and the desirable outcome of the dialogue is to achieve an acceptable resolution or new course of action.

Even though an "issue" in one environment cannot be construed as universal, there are currently legitimate matters of general concern which undergraduate librarians cannot ignore. They are emerging, not only as library systems and programs develop, but also as we experience change in institutional expectations and constraints.

At the 1977 ALA Midwinter Convention meeting of the ACRL Undergraduate Librari- ans Discussion Group, some of the significant problems were identified and the issues were skirted-even pushed by a few of the participants toward an open forum-but the discussion was notable in that the debatable and controversial issues were not clearly engaged. There were some impressive labels applied to describe the drift of the meeting ("needs of users" and "the role of the UGL"), but these were never developed beyond being convenient semantic hooks. What emerged was a preoccupation with the uncertainties and apprehensions produced by the function of local library management and with the need to exchange howto information on specific systems and services. (In all fairness, the meeting was intended as a planning session for the Detroit Conference. Further, some of the more vocal at the meeting were not "undergraduate" librarians, but fouryear undergraduate institution librarians. They were welcome, but their outspoken views skewed the group's purpose and compromised its effectiveness.)

Discussions on the internal operations and procedures of undergraduate libraries are appropriate and should be encouraged, but it is impossible to realize the potential of an undergraduate library - or any library, for that matter-through a continuous examination of such topics. Undergraduate libraries are too often characterized in terms of effective reserve procedures, automated circulation systems, security controls, and response-based library instruction programs; but these alone will be self-defeating. They are merely tools or elements in a much larger programmatic arena which has far- 